\title{
Modern Concepts of Alzheimer's Disease Pathogenesis: Novel approaches to Pharmacotherapy (Review)
}

D01: $10.17691 / \mathrm{stm} 2015.7 .3 .19$

Received August 20, 2014

Y.K. Komleva, MD, PhD, Associate Professor, Department of Biochemistry with Courses of Medical,

Pharmaceutical and Toxicological Chemistry;

N.V. Kuvacheva, PhD, Associate Professor, Department of Biochemistry with Courses of Medical,

Pharmaceutical and Toxicological Chemistry;

0.L. Lopatina, PhD, Associate Professor, Department of Biochemistry with Courses of Medical,

Pharmaceutical and Toxicological Chemistry;

Ya.V. Gorina, PhD, Associate Professor, Department of Biochemistry with Courses of Medical,

Pharmaceutical and Toxicological Chemistry;

O.V. Frolova, Researcher, Scientific Research Institute of Molecular Medicine and Pathobiochemistry;

E.A. Teplyashina, Tutor, Department of Biochemistry with Courses of Medical, Pharmaceutical and Toxicological Chemistry;

M.M. Petrova, MD, DSc, Professor, Head of the Department of Ambulatory Therapy, Family Medicine and Healthy Lifestyle;

A.B. Salmina, MD, DSc, Professor, Head of the Department of Biochemistry with Courses of Medical,

Pharmaceutical and Toxicological Chemistry, Head of Scientific Research Institute of Molecular Medicine

and Pathobiochemistry

Krasnoyarsk State Medical University named after Professor V.F. Voino-Yasenetksy, 1 Partizana Zheleznyaka St., Krasnoyarsk, 660022, Russian Federation

The review concerns the novel approaches to Alzheimer's disease pathogenesis represented in modern scientific literature, and aims at studying new possible targets for targeted pharmacotherapy of different stages of neurodegeneration. The multi-factorial disease results in disability and the loss of memory and cognitive functions causing life quality deterioration and the loss of legal capacity. The situation seems to be critical due to the fact that the majority of approved pharmaceuticals have just a symptomatic action rather than an adequate effect. For this reason there is the search for new target molecules for pharmacological intervention. Moreover, novel pharmaceuticals with more selective effect are being developed now.

Modern concepts of Alzheimer's disease pathogenesis are based on the recognized significance of the following pathological processes: neuronal damage and death, impaired neurogenesis and cell-to-cell interactions, neuroinflammation and vasculopathy development, while the accumulation of damaged proteins can be both a trigger mechanism, and also the result of the mentioned events. Based on the above stated ideas, there being developed the pharmacological approaches aimed at preventing pathologically damaged proteins from accumulating in brain, arresting aberrant neurotransmission, the correction of neuroinflammation and impaired neurogenesis, as well as the recovery of cell-to-cell interactions.

The use of adequate animal models of Alzheimer's disease is one of promising approaches to the development of novel pharmacotherapeutical strategies.

Key words: Alzheimer's disease; neurodegeneration; target-molecules; pharmacotherapy of Alzheimer's disease.

Due to a high incidence and extreme severity, Alzheimer's disease (AD) becomes a serious medical and socioeconomic problem of the modern civilized world, and its significance will be steadily growing as the population ages [1]. According to the World Alzheimer
Report 2012 there were 36 million people with $A D$ in 2009 worldwide, the number of patients doubling every 20 years, and their quantity is expected to reach 66 million by 2030 , and 115 million by 2050 [2].

Genes and environment are recognized to play an

For contacts: Salmina Alla Borisovna, e-mail: allasalmina@mail.ru 
important role in the complex etiology of $A D$ [3]. Sweden investigators classify the disease into pathogenically various forms [4]: familial, i.e. a hereditary form of presenile $A D$; senile dementia of Alzheimer's type; atypical $A D$ with the predominant front-lobe degeneration, and dementia of Alzheimer's type in patients with Down's syndrome. Advanced age is the main risk factor, which may be illustrated by statistical data: there is a twofold increase of the risk factor for every 5 years after 65 years of age, growing from 3 cases per 1,000 manyears at 65 years up to 69 cases by 95 years [5]. About $43 \%$ of patients are at the age period from 75 to 85 [6]. Illiteracy and poor education are also risk factors for $A D$ development [7]. Genetic predisposition may also serve one of the AD risk factor. Apolipoprotein E- $\varepsilon 4$ (APOE ${ }_{\varepsilon 4)}$ and its receptor SORL1 are referred to the leading genetic risk factors of $A D$ development [8]. Patients in the more advanced age suffer from sporadic forms of $A D$, with manifestations of the disease occurring usually at $60-70$ years [8]. Though patients with sporadic diseases compose the major part of the affected people, $10-15 \%$ of patients have genetically-linked family forms of $A D$. Early onset of the disease is typical for them, and it is connected with mutations in several genes, including APP, tau and presenilin-1 [9].

There exist numerous hypotheses of $A D$ etiology. Most commonly it is linked not only with genetic defects [10], but with disorders caused by lentiviruses [11], energy metabolism impairment [12], neurotrophic factor deficiency [13], excitotoxicity, mitochondrial defects, neurotoxicity of microelements and oxidative stress [14].

Advances in the methods of effective diagnosis and management of central nervous system damage are determined by the extent of knowledge about the cellular and molecular mechanisms of brain injury. The following pathologic processes are currently recognized significant for AD pathogenesis: neuron damage and death (apoptosis, autophagy), impairment of neurogenesis and cellular interactions, neuroinflammation and vasculopathy development, whereas accumulation of the damaged proteins may equally be a triggering mechanism and the result of the mentioned events.

\section{Pharmacotherapy oriented to preventing accumulation of pathologically changed proteins in the brain}

Alzheimer's disease is a neurodegenerative disease characterized by the two pathological signs - presence of senile plaques and neurofibrillary tangles in the brain. Tangles are extracellular deposits of amyloid, consisting mainly of amyloid-beta $(A \beta)$, formed by proteolysis of amyloid beta precursor protein (APP) by $\beta$ - and $\gamma$-secretases $[15,16]$. Neurofibrillary tangles represent intraneuronal aggregations of hyperphosphorylated tau protein.

Pathologic accumulation of $A \beta$ is the result of imbalance between the levels of $A \beta$ production, its aggregation and clearance. Clearance of amyloid is mediated by proteolytic enzymes, such as neprilysin [17]; molecular chaperones (e.g. APOE) [18]; lysosomal (e.g. autophagy) [19] and non-lysosomal pathways (e.g. by proteosomes) [20]. In familial forms of AD mutations result in increase or aggregation of $A \beta$, whereas in sporadic forms the deficit of clearance mechanisms may play a central role.

A bulk of evidence suggest that direct pathologic accumulation of $A \beta$ oligomers in the nervous endings may lead to synaptic damage and, finally, to neurodegeneration in $A D$ [21]. A number of scientists started to investigate the possibility of beta oligomers to affect synaptic functions by changing such synaptic proteins as postsynaptic density proteins 95 (PSD95) [22] and glutamate receptors [23]. Thus, the potential role of neurotoxic $A \beta$ oligomers has attracted great interest in recent years [24]. On the whole, impairment in the proteolytic processing of APP, resulting in the increase of production and accumulation of neurotoxic forms of $A \beta$ in the brain, play a key role in the dysfunction and death of neurons in AD [25]. Three main enzymes are known to affect the APP processing: $\alpha-, \beta$ - and $\gamma$-secretases [26]. Secretase BACE1 (beta-site APP-cleaving enzyme 1) $\beta$-secretase - is one of the main targets in AD.

Inhibition of aberrant $A \beta$ production. At present, possible application of inhibitors BACE1 for AD treatment are being discussed. BACE1-mediated cleavage of APP is the first step in generating pathogenic $A \beta$ peptides. Several approaches for searching effective inhibitors of human BACE1 have been undertaken [27]. Some of the potential inhibitors are OM99-2, GSK 188909 and CTS-21166, which have high sensitivity to $\beta$-secretase. Compound CTS-21166 is in the first phase of its clinical trials [28]. Another potential target in the therapy of $A D$ is $\gamma$-secretase due to its involvement in the regulation of $A \beta$ formation. In spite of its bioavailability and a good penetration in the brain, toxicity connected with inhibition of $\gamma$-secretase remains one of the main limitations in this pharmaceutical approach [29]. DAPT was the first dipeptide compound with an inhibiting activity of $\gamma$ secretase, which has passed trials in vivo [30].

It has been also established, that proteolysis of APP mediated by $\alpha$-secretase is not amyloidogenic and prevents $A \beta$ formation [31]. Thus, stimulation of $\alpha$ secretase can diminish formation of $A \beta$ and increase production of the soluble APP form, which potentially possesses neuroprotective properties [32]. Etasolate or EHT-0202 is a compound stimulating neuron $\alpha$ secretase and increasing production of the soluble APP form [32]. This substance has been tested in phase II clinical trials in patients with a mild and moderate degree of $A D$ [33]. One more new substance - bryostatin-1 - is a macrocyclic lactone, which can stimulate $\alpha$-secretase by activating protein kinase $\mathrm{C}$ and provide synthesis of soluble APP [34]. Bryostatin-1 is currently in phase II 
clinical trials for evaluation of its safety in patients with a mild or moderate degree of AD. Exebryl also modulates $\alpha$ - and $\beta$-secretase activity, decreasing $A \beta$ formation and accumulation in the brain of mice with $A D$ with subsequent memory improvement [35].

Increase of $\boldsymbol{A} \boldsymbol{\beta}$ clearance rate. One more promising method of AD treatment is increase of amyloid clearance, which may be achieved by application of antibodies and chaperone proteins (e.g. HSP70) [36]. Therefore, immunotherapy, using vaccination and especially passive immunization by monoclonal antibodies, is the most intensively developing area in the recent decade. Antibodies are attractive preparations, as they are highly specific for the targets and do not possess marked side-effects. However, trials of the first anti-amyloidbeta (anti-A $\beta$ ) vaccine AN1792, developed by Elan company (Ireland), were stopped in stage II because of aseptic meningoencephalitis development [37]. Nevertheless, their further investigations in patients, receiving immunization by antibodies against $A \beta$, showed improvements of cognitive functions, confirming the possibility of using immunization for treatment of AD. The use of bapineuzumab - monoclonal antibodies against fibrillar form of $A \beta-$ was also discontinued, as it failed to give any clinical effect. Solanezumab was developed for targeted effect on monomeric forms of $A \beta$, but its trials were unsuccessful as well. But comparing the data of the two investigations it was established that these preparations slow down the development of cognitive disorders in patients with $A D$ at early stages.

Monoclonal antibodies mAb158 were devised for target action on $A \beta$ protofbrils. Their selectivity to protofibrils appeared to be at least 1,000 times higher than that of monomers $A \beta$ [37], besides they decrease protofibril level by $42 \%$. The effect depends on the duration of exposure. The quantity of monomers $A \beta$ 1-42 is not observed to change, which confirms the ability of mAb158 to bind and decrease selectively soluble $A \beta$ protofibrils.

Human antibodies BAN2401 have passed the first complete phase of clinical trials and the findings obtained show a favorable profile of safety in patients with AD. The trials are already in phase 2b, and BAN2401 are likely to be a promising candidate for immunotherapy at early stages of AD [37].

Presently, the possibility of reducing $A \beta$ accumulation is being investigated, including antiaggregating molecules, blocking $A \beta$ oligomers and fibrils or hyperphosphorylated tau protein [36].

Studies on mice showed, that inhibition of sirtuins (HDAC), - a family evolutionally conservative NAD+dependent proteins possessing deacetylase or ADPribosyltransferase activity, which function as key regulators of numerous pathways related to longevity, metabolism, cell cycle, - diminishes formation of hyperphosphorylated tau protein, increases production of acetylated $\beta$-tubulin, and restores the memory in transgenic mice with $A D$ [38]. Besides, disregulation of expression and activity of sirtuins is known to be characteristic for brain aging [39].

Whereas immunotherapy with the appropriate anti$A \beta$-antibodies has already passed several phases of clinical trials, tau-based immunization was analyzed only on mice. Since there was established a considerable correlation between progressing dementia and the levels of phosphorylated tau protein, further development of treatment methods based on anti-tau immunization is of great interest. Tau protein is a key link in the $A D$ progressing, and therefore, is a suitable target for immunization. Passive immunization with specific antibodies lgG2a/k pS404 resulted in the reduction of plaque deposition and phosphorylated of tau protein [40]. While $A \beta$-immunotherapy can delay onset of $A D$, tau-oriented immunotherapy is believed to provide advantages at the later stages of the disease [41].

Clearance of amyloid is mediated by proteolytic enzymes, such as neprilysin [17], molecular chaperons [18], enzymes of lysosomes and proteasomes [19, 20]. A rather promising method of neprilysin delivery to the brain tissue mediated by the stem cells is being developed, reducing essentially $A \beta$ deposition and increasing synaptic density. It is noteworthy, that amyloid plaques diminish not only in the hippocampus and brain region, where the stem cells are transplanted, but also inside the amygdala and medial septum - the areas which receive afferent projections from the immunized region. The overall data show, that genetically modified stem cells can be a powerful combined approach for rising synaptic plasticity and reducing the deposition of plaques [42, 43].

Since amyloid clearance needs not only amyloiddegrading enzyme neprilysin but lysosomal hydrolases as well, the analysis of molecular cascade events, leading to autophagia, may present bases for the development of new drugs capable to treat progressing AD. Autophagia as a self degradation of cellular components is regulated by various signaling factors including beclin-1 protein, autophagia effector participating in autophagosome formation [44], and "the mammalian target of rapamycin" (mTOR protein), which is a negative regulator of autophagia [45]. In transgenic mice with $A D$, having the deficit of beclin-1, an elevated aggregation of $A \beta$ is observed, and hyperexpression has a counter-effect. Besides, studying the brain bioptates in patients suffering from $A D$, the decrease of beclin-1 expression level was found [46].

There was also found an increase of mTOR expression in $A D$, which positively correlates with deposition of $A \beta$ and tau protein and decline of cognitive functions [47]. And vice versa, inhibition of mTOR delays AD progression in transgenic mice [48]. Mechanical reduction of $m$ TOR signaling results in increase of autophagia induction and restoration of hippocampal gene expression. Besides, hyperactive signaling with participation of mTOR may 
represent a molecular pathway by which aging promotes progression of $A D$ [26].

These data suggest that a more rapid elimination of the damaged cell components and proteins by increasing autophagia may prevent neurons death. And in this context application of autophagia stimulators can be a permissible therapeutic approach for $A D$ management. And this prerequisite inspired the search of autophagia modulators, and some small molecules were tested as stimulators of autophagia (rapamycin, temsirolimus) [26].

\section{Pharmacotherapy, oriented to arresting aberrant neurotransmission}

The most common preparations used currently for $A D$ treatment are inhibitors of acetylcholinesterase (ACE). As the cholinergic neuronal activity in $A D$ is known to decrease, inhibitors of ACE slow down the process of acetylcholine destruction, increasing its concentration in the brain. The increase of cholinergic neurotransmission is an effective way of preventing symptoms and progression of $A D$. Thus, inhibition of $A C E$, which is responsible for metabolic breakdown of acetylcholine, is now considered as the most perspective approach. Currently four "classic" preparations, acting as ACE inhibitors, are used: donepezil, galantamine, rivastigmine and tacrine. The development of new and potent preparations for $A D$ are going on, and $A C E$ inhibitors remain rather viable target for symptomatic improvement of $\mathrm{AD}$ [49].

The development of more effective anticholinesterase preparations with minimal side-effects and better pharmacokinetics is a priority research area. At present, novel ACE inhibitors with higher affinity and selectivity are being looked for. Search for natural compounds with anticholinesterase activity and development of inhibitors with double binding, which can interact with central and peripheral parts of the enzyme is the main orientation. Previous investigations [26] of the ACE structure and function showed, that this enzyme has two binding sites - catalytic anion site (CAS) and peripheral anion site (PAS). PAS is supposed to promote deposition and aggregation of $A \beta$ in the brain. Therefore, multibinding inhibitors, which can suppress catalytic activity of ACE and prevent $A \beta$ self-assembly, may become more effective agents for AD treatment [26].

New ACE inhibitors can be divided into two major categories depending on the origin of the compounds natural and synthetic. Alkaloids pertain to the natural ACE inhibitors. They are contained in plants, some of which are used as alternative medicinal agents in China and India. These compounds include huperzine A, huperzine $B$, berberine and their semi-synthetic derivatives. There are also tacrine derivatives, possessing the activity of the inhibitor with double-site binding [26]. PMS777 is referred to ACE inhibitors, representing tetrahydrofuran derivative of ACE inhibitor with an additional factor, directed against thrombocyte activation (anti-PAF). The thrombocyte activation factor is a powerful antiinflammatory mediator, which causes microglia hemotaxis and activates expression of anti-inflammatory cytokines, intensifying inflammation in the brain, which contributes to $A D$ progressing [50].

Antagonists of glutamate NMDA receptors, suppressing the processes of excitotoxicity, are used for symptomatic treatment of AD. These preparations improve cognitive functions, but have a limited effect on the clinical course of the disease. Extreme activation of NMDA receptors and subsequent entry of $\mathrm{Ca}^{2+}$ into the cell was shown [51] to cause cells death in the brain in strokes and AD. Abnormal glutamatergic activity, associated with $A D$, may be connected with postsynaptic receptors and impairment of NMDA receptor activation, which results in the damage and death of neurons and cognitive disorders related to dementia [52]. Mechanisms, leading chronically depolarized membranes on susceptible neurons in $A D$, are likely to realize due to complex interaction between the pathological links of the oxidative process, mitochondrial deficit, chronic inflammation and presence of $A \beta$ and hyperphosphorylated tau protein in the brain. In spite of the controversial data on functioning NMDA receptors in $A D$ and dementia, reduction of the quantity of NMDA receptors is proved to be typical for such pathological conditions: decrease of NMDA receptor expression, in particular, by $20 \%$ was found in the frontal cortex [53]. Therefore, in recent years main attention has been paid to improvement of memory by activation of cholinergic neurotransmission using antioxidants and calcium channel blockers [36].

\section{Pharmacotherapy, oriented to neuroinflammation and aberrant neurogenesis correction}

Neurodegenerative processes in $A D$ are characterized by the damage of synapses, accompanied by the loss of neurons. This is associated with astrogliosis, proliferation of microglia cells and presence of neurofibrillary tangles, consisting of dystrophic neurites and hyperphosphorylated tau protein. Moreover, recent data [54] demonstrate the role of the impaired neurogenesis in hippocampus. Impairments of neurogenesis typical for a grown-up organism are accompanied by inhibition of proliferative activity of neuronal stem and progenitor cells, astroglia dysfunction, failure of postmitotic neurons to be included into new synaptic contacts, and abnormal production of the key neurotrophic factors. Elimination of synapses markedly correlates with cognitive disorders in patients suffering from AD.

An important component of $A D$ pathogenesis is neuroinflammation, the activity of which is mediated not only by microglia, showing cytotoxic potential in relation to the damaged neurons, but also by astroglial cells, participating in the regulation of a local inflammation, producing cytokines and forming multiprotein 
complexes — inflammasomes, providing intracellular proteolysis of proinflammatory cytokines.

One of the up-to-date pharmacotherapeutic approaches to $A D$ is protection of the selected neuronal populations, as well as neurogenesis stimulation and formation of synapses [36]. Formation of synapses represents a dynamic process with participation of pre- and postsynaptic cells and a number of factors, receptors, signaling molecules and adhesion molecules. Such proteins as neuroligins, neurexines and thrombospondin directly promote formation of synapses [55]. It was demonstrated [56], that inhibition of histone deacetylase HDAC1, determining some variants of epigenetic regulation, provides formation and maturation of synapses. Then screening of new derivatives of hydroxamic acid was carried out and their probable inhibition of histone deacetylase was studied. Some derivatives were found to influence synapse formation. A promising therapeutic target for $A D$ treatment, HDAC6, is also under discussion [57]. The potential of the two selective inhibitors HDAC6 - tubastatine $\mathrm{A}$ and $\mathrm{ACY}-125$ - is seen in improvement of behavior, cognitive functions, reduction of amyloid deposition and decrease of hyperphosphorylated tau protein without apparent side-effects. These observations encourage the development of selective HDAC inhibitors as a potential therapeutic strategy for managing $A D$ and neurological disorders. Nowadays, HDAC inhibitors (e.g. panobinostat) are available. They can block unselectively more than one deacetylase, causing unfavorable effects [56]. Creation of selective histone deacetylase inhibitors may provide a new approach to the regulation of synaptogenesis.

Rather challenging is also regenerative medicine, which uses cell technologies and other means, directed to modulation of neurogenesis. Neurogenesis in the mature brain continues in two regions hippocampus and subventricular zone. As progressing of $A D$ negatively affects neurogenesis, conditions, which stimulate endogenic neurogenesis (enriched medium, physical activity, trophic factors, cytokines), can promote regenerative processes in the brain [58]. For example, erythropoietin stimulates neurogenesis, causing neuroprotective effect and proving the possibility of its use in AD [59]. There was developed the technology of intranasal delivery of plasma rich in growth factors (PRGF-Endoret). Endoret could activate neuron cellprecursors, stimulate hippocampal neurogenesis, and reduce amyloid-induced neurodegeneration in $A D$ [60].

$A D$ development is often accompanied by vasculopathy, caused by amyloid deposition in the cerebral vessels, toxic effect of amyloid and tau protein in the cerebral endothelial cells, oxidative stress, microcapillary damage, local inflammation, microthrombosis. Thus, thrombin concentration in the brain cortex and microvessels in $A D$ is known to be elevated, which causes direct neurotoxic effect and proinflammatory effects in endothelial cells, microglia and astrocytes [61]. Besides, diabetes- and hypoxia-induced cerebrovascular effects are shown to be mediated by thrombin. Thrombin inhibitors block hypoxia action on brain endothelial cells and inhibit amyloid vasculopathy in transgenic mice with $\mathrm{AD}$ [61].

Transplantation of placenta-derived mesenchymal stem cells (PD-MSCs) is found to improve significantly cognitive functions, reduce APP, BACE1 and A $\beta$ expression, as well as $\beta$ - and $\gamma$-secretase activity [62]. Additionally, transplantation of PD-MSC inhibits glial cell activation and expression of induced nitric oxide synthase and cyclooxygenase-2. PD-MSCs provide neuroprotection regulating neuron death, neurogenesis, glia activation in hippocampus and alterations of cytokine expression, which shows a close connection between therapeutic effects of mesenchymal stem cells and AD [62]. However, implementation of novel technologies of regenerative medicine, including usage of induced pluripotent stem cells, in neurodegeneration needs essential evidence base.

Data obtained by the authors [63] show that stimulation of adult neurogenesis by creation of enriched environment with a high content of social and nonsocial stimuli are of great importance for $A D$ development in rodents. There were established new mechanisms by which enriched environment affects neurogenesis and synaptogenesis in physiological aging and experimental AD. Enriched environment was shown to effectively trigger apoptosis and early cell proliferation, but cannot influence later events, accompanying acquisition neuronal rather than glial phenotype by the cell in experimental AD model. Thus, neurogenesis stimulation is an attractive approach to $A D$ therapy, but elaboration of the protocols of neurogenesis-stimulating effects is a task for a large number of investigators and clinicians.

\section{Pharmacotherapy, oriented to the correction of intercellular interactions}

Impairment of intercellular interconnections, e.g. neuron-astroglia, and also interactions of the cells having neuronal and glial nature with extracellular matrix plays an essential role in $A D$ pathogenesis. Amyloid toxicity is known [63] to be caused by impairment of neuronastroglial metabolic coupling, inhibition of glycolysis and mitochondrial activity, glucose transport, and development of local insulin resistance, which alter cell functional activity and is the basis of cognitive dysfunction, progressing neurodegeneration, and neuroinflammation.

Extracellular matrix is known to play an important role in the regulation of neuroplasticity [16]. It is not surprising, that the probable target, which possesses the activity similar to $\alpha$-sectetase, is matrix metalloprotease-9 (MMP-9), participating in matrix remodeling and proteolysis of some peptide factors. MMP-9 secretion is provided by the cells of activated microglia and astroglia, that corresponds to the development of 
neuroinflammation. MMP-9 is found to take part in neuronal plasticity and to reduce $A \beta$ level. Functionally, hyperexpression of MMP-9 prevents cognitive deficit, increasing the quantity of presynaptic protein synaptophysin and brain-derived neurotrophic factor (BDNF). These findings suggest that activation of endogenous MMP-9 may be a viable target for $A D$ therapy [64].

In terms of pathophysiology, blocking of signal pathways and receptors, activating neurotoxicity of $A \beta$ oligomers, is also an attractive direction. It was demonstrated [36], that signaling proteins, including Fyn-kinase, glycogen synthase kinase-3 (GSK-3) and cyclin-dependent kinase-5 (CDK5), participate in neurodegenerative process in AD [36]. In this connection preparations inhibiting the activity of these proteins are under development. For example, GSK-3 serves as a target for different kinds of substrates, i.e. metabolic proteins (e.g. APP and presineline) [65], structural proteins (tau and other proteins, connected with microtubules) [66], and transcription factors (e.g. NF-kB, p53 and Notch) [67]. Therefore inhibitors GSK-3 are valuable candidates for new investigations of possible ways of $A D$ treatment. Several inhibitors GSK-3 were described in the literature, including univalent lithium cation [68]. The results have shown, that small doses of lithium strongly influence the process of restoration of impaired learning function and memory, facilitating hippocampal long-term potentiation, reduce $A \beta$ deposition and the levels of phosphorylated tau. Derivatives of structurally various chemical groups such as thiazolidinediones, paullones, maleimides, indirubins and diverse natural alkaloids, isolated from spongia are used with the same purpose [69].

One more protein, participating in the development of degenerative mechanisms, associated with $A D$, is a receptor of nerve growth factor - p75-neurotrophinereceptor (p75NTR). Expression levels of p75NTR were found to be increased in AD. This fact demonstrates that modulation of p75NTR expression may be a hopeful approach to the disease treatment [70], while mechanical elevation of the neurotrophic factor levels does not give any marked therapeutic effect.

It should be noted, that in addition to toxicity of $A \beta$ and tau, the importance of which for AD pathology has already been proved, caspases and apoptotic cascade are also involved in the degenerative process [71]. A large number of works has been devoted to the study of apoptosis in neurodegeneration in the last 20 years. Apoptosis can be inhibited using inhibitors of caspases such, for example, as carbobenzoxy-valyl-alanyl-aspartyl [O-methyl]fluoromethylketone (Z-VAD-FMK) [72]. The properties of minocycline are also known: it is a highly lipophilic semi-synthetic analog of tetracycline, which penetrates through hematoencephalic barrier, inhibits cytochrome C, and prevents caspase 3 activation [73]. However, application of apoptosis modulators does not as yet demonstrate a marked therapeutic effect in neurodegenerative conditions, which can partly be explained by the fact, that apoptosis, as a physiological phenomenon, and activated in 1152

ts presence caspases, are involved in plenty of mechanisms in the central nervous system, including memorizing process and neuroplasticity.

\section{Searching new target-molecules by modeling Alzheimer's disease on animals}

One of the prospective approaches to the development of pharmacotherapeutic strategies is the usage of adequate $A D$ models on animals. Such models were developed taking into consideration genetic mutations. Besides, there are a number of models, which express a high level of mutant APP and summarize neuropathologic, neurodegenerative, and behavioral characteristics of the disease in a man [74].

While developing transgenic models, the majority of efforts were focused on hyperexpression of mutant APP in combination with mutant PS1. For example, transfection of the mutant APP form reproduces causes of familial forms of the disease due to APP mutation. The developed transgenic models on animals demonstrated, that it is possible to reproduce some aspects of $A D$ for a short period of time, with the clinical picture and neuropathologic changes appearing in 6-15 months, while expression of neurodegeneration markers displays region-specific character: various models of amyloid deposition may depend on the definite neuronal population, expressing a faulty gene, expression level, and topographic transgene distribution, as well as the levels of $A \beta 1-40$ and $A \beta 1-42$. Numerous investigations of the modeled animals resulted in a deeper understanding of neuropathologic changes and some pathologic processes involved in the pathogenesis of Alzheimer's disease; however, molecular mechanisms are not yet clear, and other less studied disorders may play a certain role in cognitive impairments in AD [54].

In some cases the mechanism of damage development may not at all be related to the real lesion, e.g. mutation of the gene, coding tau protein, is not described in $A D$, but in transgenic mice, hyperexpressing mutant tau protein, the clinical picture of $A D$ usually develops and agglomerates of tau are formed, and the symptoms are determined by their localization. In other words, this model is useful for understanding how tau agglomerates provoke the development of neurological dysfunction.

Application of the models, utilizing direct cytotoxic effect of amyloid or chemical substances, impairing its metabolism (d-galactose, aluminium chloride), together with transgenic models allows identification of new target-molecules for pathogenetic therapy of Alzheimer's type neurodegeneration [54, 62, 72].

Presently, novel approaches including vaccination, stimulation of neurogenesis and synaptogenesis are 
Novel approaches to pharmacotherapy of Alzheimer's disease

\begin{tabular}{|c|c|c|c|}
\hline Class & Target molecule & Examples & Mechanism of action \\
\hline Inhibitors of acetylcholinesterase & Acetylcholinesterase & $\begin{array}{l}\text { Indole-containing compound } \\
\text { based on benzylpyridine; } \\
\text { Tacrine-containing compound } \\
\text { (bis-tacrine) [75] }\end{array}$ & $\begin{array}{l}\text { Dual binding of acetylcholinesterase } \\
\text { inhibitors }\end{array}$ \\
\hline Antagonists of NMDA receptors & NMDA receptors & Oxazolopiperidone lactams [76] & $\begin{array}{l}\text { Inhibition of NMDA receptor activation } \\
\text { (a more active action compared } \\
\text { to Amantadine) }\end{array}$ \\
\hline \multirow[t]{3}{*}{ Regulators of APP proteolysis } & $\beta$-secretase & $\begin{array}{l}\text { OM99-2, GSK } 188909 \\
\text { and CTS-21166 [32] }\end{array}$ & Blockage of $\beta$-secretase \\
\hline & $\gamma$-secretase & DAPT [77] & Blockage of $\gamma$-secretase \\
\hline & $\alpha$-secretase & $\begin{array}{l}\text { Etazolate or EHT-0202 } \\
\text { Bryostatin-1 [30] }\end{array}$ & By increasing $\alpha$-secretase activity \\
\hline Anti-aggregation molecules & Sirtuins (SIRT2) & AC 93253 [78] & Selective SIRT2 inhibition \\
\hline \multirow[t]{2}{*}{$\begin{array}{l}\text { Antibodies increasing clearance } \\
\text { of amyloid-beta and tau protein }\end{array}$} & Amyloid-beta & $\begin{array}{l}\text { Human antibodies to } A \beta \\
\text { BAN2401 [40] }\end{array}$ & Selective binding with $A \beta$ protofibrils \\
\hline & Tau protein & $\begin{array}{l}\text { Antibodies to tau protein } \lg \mathrm{G} 2 \mathrm{a} / \kappa \\
\mathrm{pS} 404 \text { [79] }\end{array}$ & Selective binding to tau protein \\
\hline $\begin{array}{l}\text { Substances increasing amyloid-beta } \\
\text { clearance by increasing degradation }\end{array}$ & Neprilysin & $\begin{array}{l}\text { Stem cells-mediated neprilysin } \\
\text { delivery [42] }\end{array}$ & Proteolysis of $A \beta$ \\
\hline $\begin{array}{l}\text { Substances increasing amyloid-beta } \\
\text { clearance by lysosomal pathways }\end{array}$ & mTOR & Rapamycin [80] & $\begin{array}{l}\text { Inhibition of mTOR-signaling promotes } \\
\text { reduction of amyloid-like deposits } \\
\text { and memory preservation }\end{array}$ \\
\hline \multirow{2}{*}{$\begin{array}{l}\text { Substances blocking signaling } \\
\text { pathways and receptors, activating } \\
\text { neurotoxicity of } A \beta \text { oligomers }\end{array}$} & GSK-3 & Lithium microdoses [70] & GSK-3 activity inhibition \\
\hline & $\begin{array}{l}\text { p75 neurotrophin } \\
\text { receptor (p75NTR) }\end{array}$ & $\begin{array}{l}\text { Ligands LM11A-31, LM11A-24 } \\
\text { [68] }\end{array}$ & $\begin{array}{l}\text { Blocking amyloid-beta-induced signaling } \\
\text { and neurodegeneration }\end{array}$ \\
\hline $\begin{array}{l}\text { Substances regulating other } \\
\text { pathways in } A D \text { pathogenesis }\end{array}$ & Thrombin & Thrombin inhibitors [61] & $\begin{array}{l}\text { Blocking hypoxia effect on the brain } \\
\text { endothelial cells and inhibition } \\
\text { of vasculopathy development }\end{array}$ \\
\hline
\end{tabular}

used in addition to the traditional methods of developing pharmaceutical strategy (See the Table). Nevertheless the problem of $A D$ management remains unsolved and demands searching new target-molecules for effective pharmacotherapy.

Research Funding. The work was supported by RF President's grant for the state support of the leading scientific schools of the Russian Federation (HШ1172.2014.7).

Conflicts of Interest. The authors have no conflicts of interest related to the present study.

\section{References}

1. Popova T.F., Nesina I.A., Klimova L.A. Diagnostics and treatment of cognitive impairment of senile age in the specialized medical institution. Sibirskoe meditsinskoe obozrenie 2011; 70(4): 74-78.

2. World Alzheimer Report 2012. Overcoming the stigma of dementia. London: Alzheimer's Disease International; 2012; 80 p.

3. Wöhr M., Schwarting R.K. Affective communication in rodents: ultrasonic vocalizations as a tool for research on emotion and motivation. Cell Tissue Res 2013; 354(1): 81-97, http://dx.doi. org/10.1007/s00441-013-1607-9.

4. Gottfries C.G. Clinical classification of dementias. Arch
Gerontol Geriatr 1995; 21(1): 1-11, http://dx.doi.org/10.1016/01674943(95)00651-z.

5. Deacon R.M.J., Koros E., Bornemann K.D., Rawlins J.N. Aged Tg2576 mice are impaired on social memory and open field habituation tests. Behav Brain Res 2009; 197(2): 466-468, http:// dx.doi.org/10.1016/j.bbr.2008.09.042.

6. Bermejo-Pareja F., Benito-León J., Vega S., Medrano M.J., Román G.C. Incidence and subtypes of dementia in three elderly populations of central Spain. J Neurol Sci 2008; 264(1-2): 63-72, http://dx.doi.org/10.1016/j.jns.2007.07.021.

7. Scazufca M., Menezes P.R., Vallada H.P., Crepaldi A.L., Pastor-Valero M., Coutinho L.M., Di Rienzo V.D., Almeida O.P. High prevalence of dementia among older adults from poor socioeconomic backgrounds in São Paulo, Brazil. Int Psychogeriatr 2008; 20(02): 394-405, http://dx.doi.org/10.1017/ s1041610207005625.

8. Thies W., Bleiler L.; Alzheimer's Association Report. 2011 Alzheimer's disease facts and figures. Alzheimers Dement 2011; 7(2): 208-244, http://dx.doi.org/10.1016/j.jalz.2011.02.004.

9. Pastor P., Goate A.M. Molecular genetics of Alzheimer's disease. Curr Psychiatry Rep 2004; 6(2): 125-133, http://dx.doi. org/10.1007/s11920-004-0052-6.

10. Allain H., Bentué-Ferre D., Akwa Y. Disease-modifying drugs and Parkinson's disease. Prog Neurobiol 2008; 84(1): 25 39, http://dx.doi.org/10.1016/j.pneurobio.2007.10.003.

11. Takagi N., Logan R., Teves L., Wallace M.C., Gurd J.W. 
Altered interaction between PSD-95 and the NMDA receptor following transient global ischemia. J Neurochem 2000; 74(1): 169-178, http://dx.doi.org/10.1046/j.1471-4159.2000.0740169.x.

12. Roesler R., Vianna M.R.M., de-Paris F., Rodrigues C., Sant'Anna M.K., Quevedo J., Ferreira M.B.C. NMDA receptor antagonism in the basolateral amygdala blocks enhancement of inhibitory avoidance learning in previously trained rats. Behav Brain Res 2000; 112(1-2): 99-105, http://dx.doi.org/10.1016/ s0166-4328(00)00169-8.

13. Liu D.-D., Yang Q., Li S.T. Activation of extrasynaptic NMDA receptors induces LTD in rat hippocampal CA1 neurons. Brain Res Bull 2013; 93: 10-16, http://dx.doi.org/10.1016/j.brainr esbull.2012.12.003.

14. Butterfield D.A., Di Domenico F., Barone E. Elevated risk of type 2 diabetes for development of Alzheimer disease: a key role for oxidative stress in brain. Biochim Biophys Acta 2014; 1842(9): 1693-1706, http://dx.doi.org/10.1016/j.bbadis.2014.06.010.

15. Sisodia S.S., Price D.L. Role of the beta-amyloid protein in Alzheimer's disease. FASEB J 1995; 9(5): 366-370.

16. Mukhina I.V., Khaspekov L.G. New technologies in experimental neurobiology: neuronal networks on multiple electrode matrix. Annaly klinicheskoy i eksperimental'noy nevrologii 2010; 4(2): 44-51.

17. Iwata N., Tsubuki S., Takaki Y., Shirotani K., Lu B., Gerard N.P., Gerard C., Hama E., Lee H.-J., Saido T.C. Metabolic regulation of brain Abeta by neprilysin. Science 2001; 292(5521): 1550-1552, http://dx.doi.org/10.1126/science.1059946.

18. Kim J., Basak J.M., Holtzman D.M. The role of apolipoprotein E in Alzheimer's disease. Neuron 2009; 63(3): 287303, http://dx.doi.org/10.1016/j.neuron.2009.06.026.

19. Bendiske J., Bahr B.A. Lysosomal activation is a compensatory response against protein accumulation and associated synaptopathogenesis - an approach for slowing Alzheimer disease? J Neuropathol Exp Neurol 2003; 62(5): 451-463.

20. Marambaud P., Zhao H., Davies P. Resveratrol promotes clearance of Alzheimer's disease amyloid-beta peptides. J Biol Chem 2005; 280: 37377-37382, http://dx.doi.org/10.1074/jbc. m508246200.

21. Selkoe D.J. Translating cell biology into therapeutic advances in Alzheimer's disease. Nature 1999; 399: A23-A31, http://dx.doi.org/10.1038/399a023.

22. Gylys K.H., Fein J.A., Yang F., Wiley D.J., Miller C.A., Cole G.M. Synaptic changes in Alzheimer's disease: increased amyloid-beta and gliosis in surviving terminals is accompanied by decreased PSD-95 fluorescence. Am J Pathol 2004; 165(5): 1809-1817, http://dx.doi.org/10.1016/S0002-9440(10)63436-0.

23. Almeida C.G., Tampellini D., Takahashi R.H., Greengard P., Lin M.T., Snyder E.M., Gouras G.K. Beta-amyloid accumulation in APP mutant neurons reduces PSD-95 and GluR1 in synapses. Neurobiol Dis 2005; 20: 187-198, http://dx.doi.org/10.1016/ j.nbd.2005.02.008.

24. Walsh D.M., Selkoe D.J. Oligomers on the brain: the emerging role of soluble protein aggregates in neurodegeneration. Protein Pept Lett 2004; 11(3): 213-228, http://dx.doi.org/10.2174/ 0929866043407174.

25. Mattson M.P. Pathways towards and away from Alzheimer's disease. Nature 2004; 430(7000): 631-639, http:// dx.doi.org/10.1038/nature02621.

26. Silva T., Reis J., Teixeira J., Borges F. Alzheimer's disease, enzyme targets and drug discovery struggles: from natural products to drug prototypes. Ageing Res Rev 2014; 15 : 116-145, http://dx.doi.org/10.1016/j.arr.2014.03.008.
27. Turner A.J., Fisk L., Nalivaeva N.N. Targeting amyloiddegrading enzymes as therapeutic strategies in neurodegeneration. Ann NY Acad Sci 2004; 1035: 1-20, http://dx.doi.org/10.1196/ annals.1332.001.

28. Mangialasche F., Solomon A., Winblad B., Mecocci P., Kivipelto M. Alzheimer's disease: clinical trials and drug development. Lancet Neurol 2010; 9(7): 702-716, http://dx.doi. org/10.1016/s1474-4422(10)70119-8.

29. De Strooper B., Vassar R., Golde T. The secretases: enzymes with therapeutic potential in Alzheimer disease. Nat Rev Neurol 2010; 6(2): 99-107, http://dx.doi.org/10.1038/ nrneurol.2009.218.

30. Wolfe M.S. Inhibition and modulation of gammasecretase for Alzheimer's disease. Neurotherapeutics 2008; 5(3): 391-398, http://dx.doi.org/10.1016/j.nurt.2008.05.010.

31. Woodward M.C. Drug treatments in development for Alzheimer's disease. J Pharm Pract Res 2012; 42(1): 58-65, http://dx.doi.org/10.1002/j.2055-2335.2012.tb00133.x.

32. Marcade M., Bourdin J., Loiseau N., Peillon H., Rayer A., Drouin D., Schweighoffer F., Désiré L. Etazolate, a neuroprotective drug linking $\mathrm{GABA}(\mathrm{A})$ receptor pharmacology to amyloid precursor protein processing. J Neurochem 2008; 106(1): 392-404, http:// dx.doi.org/10.1111/j.1471-4159.2008.05396.x.

33. Desire L., Marcade M., Peillon H., Drouin D., Sol O., Pando M. Clinical trials of EHT 0202, a neuroprotective and procognitive alpha-secretase stimulator for Alzheimer's disease. Alzheimers Dement 2009; 5(4): 255-256, http://dx.doi.org/10.1016/ j.jalz.2009.04.276.

34. Etcheberrigaray R., Tan M., Dewachter I., Kuipéri C., Van der Auwera I., Wera S., Qiao L., Bank B., Nelson T.J., Kozikowski A.P., Van Leuven F., Alkon D.L. Therapeutic effects of PKC activators in Alzheimer's disease transgenic mice. Proc Natl Acad Sci USA 2004; 101(30): 11141-11146, http://dx.doi. org/10.1073/pnas.0403921101.

35. Snow A.D., Cummings J., Lake T., Hu Q., Esposito L., Cam J., Hudson M., Smith E., Runnels S. Exebryl-1: a novel small molecule currently in human clinical trials as a disease-modifying drug for the treatment of Alzheimer's disease. Alzheimer's Dement 2009; 5(4): 418, http://dx.doi.org/10.1016/j.jalz.2009.04.925.

36. Crews L., Masliah E. Molecular mechanisms of neurodegeneration in Alzheimer's disease. Hum Mol Geneti 2010; 19(R1): R12-R20, http://dx.doi.org/10.1093/hmg/ddq160.

37. Lannfelt L., Möller C., Basun H., Osswald G., Sehlin D., Satlin A., Logovinsky V., Gellerfors P. Perspectives on future Alzheimer therapies: amyloid- $\beta$ protofibrils - a new target for immunotherapy with BAN2401 in Alzheimer's disease. Alzheimers Res Ther 2014; 6(2): 16, http://dx.doi.org/10.1186/alzrt246.

38. Suzuki T., Khan M.N.A., Sawada H., Imai E., Itoh Y., Yamatsuta K., Tokuda N., Takeuchi J., Seko T., Nakagawa H., Miyata N. Design, synthesis, and biological activity of a novel series of human sirtuin-2-selective inhibitors. J Med Chem 2012; 55(12): 5760-5773, http://dx.doi.org/10.1021/jm3002108.

39. Maxwell M.M., Tomkinson E.M., Nobles J., Wizeman J.W., Amore A.M., Quinti L., Chopra V., Hersch S.M., Kazantsev A.G. The Sirtuin 2 microtubule deacetylase is an abundant neuronal protein that accumulates in the aging CNS. Hum Mol Genet 2011; 20(20): 3986-3996, http://dx.doi.org/10.1093/hmg/ddr326.

40. Ittner A., Bertz J., Suh L.S., Stevens C.H., Götz J., Ittner L.M. Tau-targeting passive immunization modulates aspects of pathology in tau transgenic mice. J Neurochem 2015; 132(1): 135-145, http://dx.doi.org/10.1111/jnc.12821.

41. Washington D., Rosenberg R.N. Anti-amyloid beta to tau-based immunization: developments in immunotherapy for 
Alzheimer disease. Immunotargets Ther 2013; 2013(2): 105-114, http://dx.doi.org/10.2147/itt.s31428.

42. Blurton-Jones M., Spencer B., Michael S., Castello N.A., Agazaryan A.A., Davis J.L., Müller F.J., Loring J.F., Masliah E., LaFerla F.M. Neural stem cells genetically-modified to express neprilysin reduce pathology in Alzheimer transgenic models. Stem Cell Res Ther 2014; 5(2): 46, http://dx.doi.org/10.1186/scrt440.

43. Balashova A.N., Dityatev A.E., Mukhina I.V. Forms and mechanisms of homeostatic synaptic plasticity. Sovremennye tehnologii v medicine 2013; 5(2): 98-107.

44. Kang R., Zeh H.J., Lotze M.T., Tang D. The Beclin 1 network regulates autophagy and apoptosis. Cell Death Differ 2011; 18(4): 571-580, http://dx.doi.org/10.1038/cdd.2010.191.

45. Kim J., Kundu M., Viollet B., Guan K.L. AMPK and mTOR regulate autophagy through direct phosphorylation of Ulk1. Nat Cell Biol 2011; 13(2): 132-141, http://dx.doi. org/10.1038/ncb2152.

46. Pickford F., Masliah E. The autophagy-related protein beclin 1 shows reduced expression in early Alzheimer disease and regulates amyloid beta accumulation in mice. J Clin Invest 2008; 118(6): 2190-2199, http://dx.doi.org/10.1172/jci33585.

47. Li X., Alafuzoff I., Soininen H., Winblad B., Pei J.J. Levels of mTOR and its downstream targets 4E-BP1, eEF2, and eEF2 kinase in relationships with tau in Alzheimer's disease brain. FEBS J 2005; 272(16): 4211-4220, http://dx.doi.org/10.1111/ j.1742-4658.2005.04833.x.

48. Spilman P., Podlutskaya N., Hart M.J., Debnath J., Gorostiza O., Bredesen D., Richardson A., Strong R., Galvan V. Inhibition of mTOR by rapamycin abolishes cognitive deficits and reduces amyloid-beta levels in a mouse model of Alzheimer's disease. PLoS ONE 2010; 5 (4): e9979, http:// dx.doi.org/10.1371/journal.pone.0009979.

49. Wilkinson D.G., Francis P.T., Schwam E., Payne-Parrish J. Cholinesterase inhibitors used in the treatment of Alzheimer's disease. Drugs Aging 2004; 21(7): 453-478, http://dx.doi. org/10.2165/00002512-200421070-00004.

50. Li J., Huang H., Miezan Ezoulin J.M., Gao X.L., Massicot F., Dong C.Z., Heymans F., Chen H.Z. Pharmacological profile of PMS777, a new AChE inhibitor with PAF antagonistic activity. Int J Neuropsychopharmacol 2007; 10 (1): 21-29, http://dx.doi. org/10.1017/s1461145705006425.

51. Scarpini E., Scheltens P., Feldman H. Treatment of Alzheimer's disease; current status and new perspectives. Lancet Neurol 2003; 2(9): 539-547, http://dx.doi.org/10.1016/s14744422(03)00502-7.

52. Wenk G.L., Parsons C.G., Danysz W. Potential role of $\mathrm{N}$-methyl-D-aspartate receptors as executors of neurodegeneration resulting from diverse insults: focus on memantine. Behav Pharmacol 2006; 17(5-6): 411-424, http:// dx.doi.org/10.1097/00008877-200609000-00007.

53. Hu N.W., Ondrejcak T., Rowan M.J. Glutamate receptors in preclinical research on Alzheimer's disease: update on recent advances. Pharmacol Biochem Behav 2012; 100(4): 855-862, http://dx.doi.org/10.1016/j.pbb. 2011. 04.013.

54. Crews L., Rockenstein E., Masliah E. APP transgenic modeling of Alzheimer's disease: mechanisms of neurodegeneration and aberrant neurogenesis. Brain Struct Funct 2010; 214(2-3): 111-126, http://dx.doi.org/10.1007/s00429-009-0232-6.

55. Kwon H.B., Kozorovitskiy Y., Oh W.J., Peixoto R.T., Akhtar N., Saulnier J.L., Gu C., Sabatini B.L. Neuroligin-1dependent competition regulates cortical synaptogenesis and synapse number. Nat Neurosci 2012; 15(12): 1667-1674, http:// dx.doi.org/10.1038/nn.3256.
56. Shi P., Scott M.A., Ghosh B., Wan D., Wissner-Gross Z., Mazitschek R., Haggarty S.J., Yanik M.F. Synapse microarray identification of small molecules that enhance synaptogenesis. Nat Commun 2011; 2: 510, http://dx.doi.org/10.1038/ ncomms1518.

57. Zhang L., Liu C., Wu J., Tao J.J., Sui X.L., Yao Z.G., Xu Y.F., Huang L., Zhu H., Sheng S.L., Qin C. Tubastatin A/ ACY-1215 improves cognition in Alzheimer's disease transgenic mice. J Alzheimers Dis 2014; 41(4): 1193-1205, http://dx.doi. org/10.3233/JAD-140066.

58. Felsenstein K.M., Candelario K.M., Steindler D.A., Borchelt D.R. Regenerative medicine in Alzheimer's disease. Trans/ Res 2014; 163(4): 432-438, http://dx.doi.org/10.1016/ j.trsl.2013.11.001.

59. Maurice T., Mustafa M.H., Desrumaux C., Keller E., Naert G., de la C García-Barceló M., Rodríguez Cruz Y., Garcia Rodríguez J.C. Intranasal formulation of erythropoietin (EPO) showed potent protective activity against amyloid toxicity in the $\mathrm{A} \beta_{25-35}$ non-transgenic mouse model of Alzheimer's disease. J Psychopharmacol 2013; 27(11): 1044-1057, http://dx.doi.org/10. 1177/0269881113494939.

60. Anitua E., Pascual C., Pérez-Gonzalez R., Antequera D., Padilla S., Orive G., Carro E. Intranasal delivery of plasma and platelet growth factors using PRGF-Endoret system enhances neurogenesis in a mouse model of Alzheimer's disease. PLoS ONE 2013; 8(9): e73118, http://dx.doi.org/10.1371/journal. pone.0073118.

61. Grammas P., Martinez J.M. Targeting thrombin: an inflammatory neurotoxin in Alzheimer's disease. J Alzheimers Dis 2014; 42(Suppl 4): S537-S544, http://dx.doi.org/10.3233/JAD141557.

62. Yun H.-M., Kim H.S., Park K.R., Shin J.M., Kang A.R., il Lee K., Song S., Kim Y.-B., Han S.B., Chung H.-M., Hong J.T. Placenta-derived mesenchymal stem cells improve memory dysfunction in an A $\beta 1-42$-infused mouse model of Alzheimer's disease. Cell Death Dis 2013; 4: e958, http://dx.doi. org/10.1038/cddis.2013.490.

63. Komleva Yu.K. Neyrogenez pri eksperimental'noy bolezni Al'tsgeymera $v$ usloviyakh obogashchennoy sredy. Avtoref. dis. ... kand. med. nauk [Neurogenesis in experimental Alzheimer's disease under the conditions of high-growth enhancement medium. PhD Thesis]. Kemerovo; 2013.

64. Fragkouli A., Tsilibary E.C., Tzinia A.K. Neuroprotective role of MMP-9 overexpression in the brain of Alzheimer's 5xFAD mice. Neurobiol Dis 2014; 70: 179-189, http://dx.doi.org/10.1016/ j.nbd.2014.06.021.

65. Takahashi-Yanaga F., SasaguriT. GSK-3beta regulates cyclin D1 expression: a new target for chemotherapy. Cell Signal 2008; 20(4): 581-589, http://dx.doi.org/10.1016/j.cellsig.2007.10.018.

66. Hernandez F., Gomez de Barreda E., Fuster-Matanzo A., Lucas J.J., Avila J. GSK3: a possible link between beta amyloid peptide and tau protein. Exp Neurol 2010; 223(2): 322-325, http:// dx.doi.org/10.1016/j.expneurol.2009.09.011.

67. Charvet C., Wissler M., Brauns-Schubert P., Wang S.J., Tang Y., Sigloch F.C., Mellert H., Brandenburg M., Lindner S.E., Breit B., Green D.R., McMahon S.B., Borner C., Gu W., Maurer U. Phosphorylation of Tip60 by GSK-3 determines the induction of PUMA and apoptosis by p53. Mol Cell 2011; 42(5): 584-596, http://dx.doi.org/10.1016/j.molcel.2011.03.033.

68. Zhao L., Gong N., Liu M., Pan X., Sang S., Sun X., Yu Z., Fang Q., Zhao N., Fei G., Jin L., Zhong C., Xu T. Beneficial synergistic effects of microdose lithium with pyrroloquinoline quinone in an Alzheimer's disease mouse model. Neurobiol Aging 
2014; 35(12): 2736-2745, http://dx.doi.org/10.1016/j.neurobiolagi ng.2014.06.003.

69. Avila J., Hernández F. GSK-3 inhibitors for Alzheimer's disease. Expert Rev Neurother 2007; 7(11): 1527-1533, http:// dx.doi.org/10.1586/14737175.7.11.1527.

70. Nguyen T.V., Shen L., Vander Griend L., Quach L.N., Belichenko N.P., Saw N., Yang T., Shamloo M., Wyss-Coray T., Massa S.M., Longo F.M. Small molecule p75NTR ligands reduce pathological phosphorylation and misfolding of tau, inflammatory changes, cholinergic degeneration, and cognitive deficits in A $\beta$ PPL/S transgenic mice. J Alzheimers Dis 2014; 42(2): 459-483, http://dx.doi.org/10.3233/JAD-140036.

71. Cavallucci V., D'Amelio M. Matter of life and death: the pharmacological approaches targeting apoptosis in brain diseases. Curr Pharm Des 2011; 17(3): 215-229, http://dx.doi.org/10.2174/1 38161211795049705.

72. Li M., Ona V.O., Guégan C., Chen M., Jackson-Lewis V., Andrews L.J., Olszewski A.J., Stieg P.E., Lee J.P., Przedborski S., Friedlander R.M. Functional role of caspase-1 and caspase-3 in an ALS transgenic mouse model. Science 2000; 288(5464): 335-339, http://dx.doi.org/10.1126/science.288.5464.335.

73. Kim H.S., Suh Y.H. Minocycline and neurodegenerative diseases. Behav Brain Res 2009; 196(2): 168-179, http://dx.doi. org/10.1016/j.bbr.2008.09.040.

74. Zhang Y.W., Xu H. Molecular and cellular mechanisms for Alzheimer's disease: understanding APP metabolism. Curr Mol Med 2007; 7(7): 687-696, http://dx.doi.org/10.2174/1566524077 82564462.

75. Akrami H., Mirjalili B.F., Khoobi M., Nadri H., Moradi A., Sakhteman A., Emami S., Foroumadi A., Shafiee A. Indolinone- based acetylcholinesterase inhibitors: synthesis, biological activity and molecular modeling. Eur J Med Chem 2014; 84C: 375-381, http://dx.doi.org/10.1016/j.ejmech.2014.01.017.

76. Pereira N.A., Sureda F.X., Esplugas R., Pérez M., Amat M., Santos M.M. Tryptophanol-derived oxazolopiperidone lactams: identification of a hit compound as NMDA receptor antagonist. Bioorg Med Chem Lett 2014; 24(15): 3333-3336, http://dx.doi. org/10.1016/j.bmcl.2014.05.105.

77. Vassar R., Kuhn P.H., Haass C., Kennedy M.E., Rajendran L., Wong P.C., Lichtenthaler S.F. Function, therapeutic potential and cell biology of BACE proteases: current status and future prospects. J Neurochem 2014; 130(1): 4-28, http://dx.doi. org/10.1111/jnc. 12715 .

78. Zhang Y., Au Q., Zhang M., Barber J.R., Ng S.C., Zhang B. Identification of a small molecule SIRT2 inhibitor with selective tumor cytotoxicity. Biochem Biophys Res Commun 2009; 386(4): 729-733, http://dx.doi.org/10.1016/j.bbrc.2009.06.113.

79. Tucker S., Möller C., Tegerstedt K., Lord A., Laudon H., Sjödahl J., Söderberg L., Spens E., Sahlin C., Waara E.R., Satlin A., Gellerfors P., Osswald G., Lannfelt L. The murine version of BAN2401 (mAb158) selectively reduces amyloid- $\beta$ protofibrils in brain and cerebrospinal fluid of tg-ArcSwe mice. J Alzheimers Dis 2015; 43(2): 575-588, http://dx.doi.org/10.3233/ JAD-140741.

80. Caccamo A., De Pinto V., Messina A., Branca C., Oddo $\mathrm{S}$. Genetic reduction of mammalian target of rapamycin ameliorates Alzheimer's disease-like cognitive and pathological deficits by restoring hippocampal gene expression signature. J Neurosci 2014; 34(23): 7988-7998, http://dx.doi.org/10.1523/ jneurosci.0777-14.2014. 